\title{
EsZik VERONIKA*
}

\section{„KÖZELEBB HOZNI A TENGERT AZ ORSZÁG SZÍVÉHEZ”. A MAGYAR TENGER MEGALKOTÁSA (1868-1914)*}

Kulcsszavak: Adria, nemzetiesített táj, szimbolikus politika, modernizáció, gőzhajózás

\section{BEVEZETÉS}

A címben foglalt célt Gonda Béla, a Kereskedelmi Minisztérium osztályfónöke, a Vaskapuszabályozás, illetve a fiumei kikötő bővítési munkálatainak felügyelője és a tengerészet fáradhatatlan népszerűsítője tűzte ki az általa alapított folyóirat első számában. ${ }^{1}$ Gonda kiemelkedő, de nem első, s nem is utolsó képviselője volt annak a roppant energiákat megmozgató kísérletnek, ami a dualizmus időszakában az ország fennhatósága alatt álló rövidke adriai partszakasznak a magyar nemzeti térbe való integrációjára irányult. A Fiume környéki földdarab eltúlozhatatlanul nagy gazdasági és geopolitikai jelentőséggel bírt, de integrációja komoly kihívást jelentett a magyar nacionalizmus számára. Nem csupán arról volt szó ugyanis, hogy a tengerpartot nem magyarok lakták - ez egyáltalán nem volt szokatlan a Magyar Királyságban. A terület hovatartozásának jogi rendezetlensége, a nemzeti térrel való diszkontinuitása (corpus separatum jellege), és a helyi elitek lojalitását biztosító türelmes, óvatos nemzeti politizálás azok a tényezők, amelyek a szokásosnál is bonyolultabbá tették a táj nemzetiesítését.

A magyar-horvát kiegyezési tárgyalások jogi értelemben nyitva maradt kérdése volt Fiume és környéke hovatartozásának problémája. A magyar javaslatot, egyfajta kondomíniumot a horvát fél elfogadhatatlannak tartotta, a várost és környékét kizárólag Horvátországhoz tartozónak volt hajlandó elismerni. Ez az álláspont értelemszerűen nem képezhetett tárgyalási alapot Magyarország számára, de az olasz többségű és irányítású város is visszautasította, hogy követet küldjön a horvát saborba. ${ }^{2}$ Az érdekütközést nem oldották fel, csupán megkerülték, amikor Deák Ferenc és a magyar országgyưlés javaslatára végül uralkodói rendelet rendezte a város helyzetét, amely ideiglenesen a közös budapesti országgyúlés hatásköre, közvetlenül pedig egy magyar kormányzó irányítása alá került. A provizóriumnak nevezett félmegoldás következtében a magyar politikai és gazdasági ambíciók szempontjából létfontosságú tengeri kikötő jogállása a korszak végéig vitatott maradt. A rendezetlenül hagyott kérdés fájdalmasan érintette a horvát területek egyesítésének elmaradása miatt csalódott horvát közvéleményt, ugyanakkor a magyar közönség szemében a tárgyalások során a három szlavóniai

\footnotetext{
* Eszıк Veronika (1985), történész, tudományos segédmunkatárs, MTA BTK Történettudományi Intézet, Budapest. E-mail: eszikveronika@yahoo.com.

** A tanulmány az NKFI FK-128978 számú projektjének támogatásával készült.

1 Gonda Béla: A Magyar Adria Egyesület feladatai. A Tenger I(1911). 1. sz. 3.

2 Soкcsevits Dénes: Horvátország a 7. századtól napjainkig. Mundus Novus, Bp., 2011. 377.
} 
megyéről (Pozsega, Verőce, Szerém) való lemondás már éppen elég nagylelkű engedménynek tűnt fel. A „kiskiegyezés” megkötése tehát, hasonlóan osztrák-magyar nagytestvéréhez, ${ }^{3}$ mindkét tárgyaló félben azt a sajátos rossz érzést keltette, hogy talán túl nagy engedményeket tett a másik fél számára. A Fiume városáért folyó rivalizálás a provizóriummal közjogi értelemben megszűnt, de a későbbi rendezés ígérete miatt a politikai diskurzus továbbra is napirenden tartotta, csupán a szimbolikus politizálás terepére szorította azt.

Ilyen körülmények között komoly tétjei voltak annak, hogy sikerül-e hatalmi reprezentációval és intenzív, sokrétű szimbólumteremtéssel befolyásolni a közvélekedést, és elfogadottá, természetessé tenni a magyar tengerpart létezését, egyáltalán, a magyar tenger kifejezést. A szókapcsolat a magyarság legszebb álmait volt hivatva kifejezni, tartalommal igyekezett megtölteni a szép-, a tudományos, az ismeretterjesztő, a turisztikai irodalom, a sajtó, a politikai diskurzus stb. Tanulmányomban igyekszem felsorolásszerűen bemutatni a fentieket, vagyis a magyar tenger mint jelkép megkonstruálásának különböző területeit, majd részletesebben a tenger birtoklásának egy konkrét módját, a magyar gőzhajózás megteremtését tárgyalom. A szöveg kétosztatúságát indokolja az is, hogy míg a sajtó, a múvészetek és a tudományok által felvállalt feladat elsősorban a magyar tengernek az anyaországgal való megismertetése volt, addig a magyar lobogó a világtengereken a nemzetközi elismerés kivívásában játszott döntő szerepet. A gőzhajó ugyanakkor nem csupán a magyar állami jelképek hordozófelülete, hanem a kor egyik legmodernebb innovációja is volt. A modern karakter és a magyar jelleg összekapcsolása olyan hangsúlyos szerephez jut az elemzett integrációs erőfeszítések során, amely mindenképpen indokolja a részletesebb elemzést.

A kutatásban felmerült sokféle forrástípus olvasása során nem csupán arra fókuszáltam, hogy az adott szöveg igyekszik-e meghonosítani a magyar tenger kifejezést, hanem azt a kérdést is igyekeztem megválaszolni, hogy e források alapján mitól is lett (volna) magyar a magyar tenger. Annak nyomait kerestem tehát, hogy hogyan, milyen funkcióval épült be az Adria és tengerpartja az integrálódó nemzeti tér tájai közé. Tanulmányom legvégén röviden megvizsgálom, hogy mennyiben tekinthető sikeresnek ez a roppant energiákat megmozgató integrációs kísérlet.

Az Adria kisajátítása természetesen nem csupán a magyar államépítési ambíciók középpontjában állt. Borut Klabjan szellemesen a „versenyfutás az Adriáért" kifejezéssel illette a különböző nemzetállamok és birodalmak közötti, valamint a Habsburg Birodalmon belüli ${ }^{4}$ rivalizálást az Adriai-tenger birtoklása terén. E vetélkedésnek szentelte Fórum rovatát az Austrian History Yearbook 2011-es kiadása, az ebben megjelent írások azonban egy kivétellel az olasz-délszláv érdekütközéseket állították középpontjukba. A szerzők közül egyedül az idézett Klabjan helyezi tágabb keretek közé az olasz-délszláv versengést, és tárgyalja az Adriához kötődő lengyel, cseh és magyar imaginációt, elsősorban a tengerrel kapcsolatos tudástermelésre koncentrálva. Kevés figyelmet szentel ugyanakkor a Magyar Királyság fél évszáza-

3 Fónagy Zoltán: Modernizáció és polgárosodás 1849-1914. Csokonai, Debrecen, 2001 (Történelmi Kézikönyvtár 5). 65.

4 A birodalmon belüli nemzetépítésről lásd Nationalizing Empires. Eds. Stefan Berger-Alexei Miller. CEU, Bp.-New York, 2014. 
dos geopolitikai jelenlétének a térségben. ${ }^{5}$ Nem haszontalan tehát, ha az Adriáért folyó versengés szereplői között a Magyar Királyságot is megjelenítjük.

\section{A MAGYAR TENGER ÉS PARTJA}

Noha a kiegyezési tárgyalások során a Fiume és a magyar tengermellék fölötti közös uralmat a horvát fél visszautasította, az ajánlatból annyi mégis megmaradt a törvényszövegben, hogy a város közvetlen környezetére zsugorított terület neve ezentúl magyar-horvát tengermellék lett. ${ }^{6}$ Hamar kialakult azonban egy csokor olyan állandósult kifejezés, amely a hivatalos formulához képest jelentés- és érzelmi többlettel bírt, Fiume „Szent István koronájának legszebb gyöngye”, a „korona fényes boglára”, az „Adria gyöngye” jelzőket kapta, míg a tengert a hazai vizek közé sorolták, és magyarnak nevezték. A sajtóban a továbbiakban folyamatos a magyar tengermellék, magyar tengerpart, a magyar tenger, illetve a tengerpartunk, tengerünk megjelölés, egy szerzőnél a magyar Riviéra, ${ }^{7}$ illetve a sűrün emlegetett „Magyar Adria” (valójában az „Adria” Magyar [Királyi] Tengerhajózási Rt. közkeletű elnevezése). Ezek a fordulatok, ahogyan a gyakori (szervezett) fiumei kirándulások is, egyszerre keltették az egzotikum és az „állampolgári otthonosság" érzetét. ${ }^{8}$

Erre a kettősségre építette sajátos tengerparti világát számos publicisztikájában és három, legalább részben az Adrián játszódó regényében Jókai Mór, aki az egyik kulcsszereplője volt a magyar tengerfogalom meghonosításának. Az Egy játékos, aki nyer (1882) címú regény nem tartozik a sikerültebb Jókai művek közé, sokak szerint éppen azért, mert megírásának politikai, és nem múvészi mozgatórugói voltak. Számunkra lényeges azonban, hogy a 19. század elejére helyezett történet romantikus díszletéül Fiume közvetlen környéke szolgált. A festői táj lakói, a morlákok, vagyis tengermellékiek, és az uszkókok, egy tisztázatlan, vegyes eredetű szláv népcsoport, Jókai víziójában vademberek, akiket nem vagy alig érintett meg a civilizáció. ${ }^{9}$ Jellemzően kólót táncolnak, véres háborúkat vívnak, ellenfeleik levágott fejeit dárdán

5 Borut Klabjan: "Scramble for Adria". Discourses of Appropriation of the Adriatic Space Before and After World War I. Austrian History Yearbook XLII(2011). 16-32. Az egymást kizáró nemzeti programok mellett multietnikus víziók is teremtek a régióban, lásd Dominique Kirchner Reill: Nationalists Who Feared the Nation. Adriatic Multi-Nationalism in Habsburg Dalmatia, Trieste and Venice. Stanford University Press, Stanford, 2012 (Stanford Studies on Central and Eastern Europe).

6 Sokcsevits: i. m. 377.

7 Döмӧтӧri Németн Péter: $A$ Quarnero vizein = Adriai képek, magyar útirajzok. Szerk. Kiss Gy. Csaba. Palatinus, Bp., 2008 (a továbbiakban Adriai képek). 340-348.

8 Kiss Gy. Csaba: Egy fejezet a magyar irodalom Fiume-kultuszából = Fiume és a magyar kultúra. Múvelódéstörténeti tanulmányok. Szerk. Kiss Gy. Csaba. ELTE BTK Művelődéstörténeti tanszékKortárs, Bp., 2004 (a továbbiakban Fiume és a magyar kultúra). 138.

9 Ez a sztereotip látásmód természetesen nem Jókai Mór invenciója. Az uszkókok már egy, a 17. században elhíresült szövegben is vérszomjas barbárokként jelentek meg, és minden bizonnyal Johann Gottfried von Herder szlávokról alkotott képe is - amelyben újdonság, hogy a civilizálatlanság nem csupán negatívum, inkább vonzó romlatlanságként érthető - hatással volt a népcsoport megítélésére. Lásd Paolo SArpi-Gaetano Cozzi-Luisa Zille-Minuccio Minucci: La Repubblica de Venezia, la Casa d'Austria e gli Uscocchi. G. Laterza \& Figli, Bari, 1965. Dominique Kirchner Reill foglalkozott továbbá Francesco Dall’Ongaro romantikus költeményeinek uszkókképével: Domi- 
hordozzák, és brutálisan bánnak asszonyaikkal. A borzongató kép alkalmas volt arra, hogy ellentétpárjaként megfogalmazódhasson egy, a civilizáció magasabb fokán álló magyarság önképe. A cselekménynek a közelmúltba, a 19. század első harmadába csúsztatása pompásan kidomborította a tengerpart vad múltja és magyar jelene közötti különbséget, míg az anyaországi olvasók kedélyét a hírlapokban rendszeresen (főként uborkaszezonban) emlegetett fiumei cápa ${ }^{10}$ fószerepbe állítása borzolta.

A három márványfej című, először 1887-ben kiadott mű 12-13. századi dalmáciai történetével csillapította a tengerpart iránt feltámadt kíváncsiságot. A régió iránt természetesen a történettudományi érdeklődés is fokozódott, Jókai képzeletére Thallóczy Lajos délszláv kutatásai hatottak a témaválasztásnál. ${ }^{11}$

Élete utolsó, már fáradtságról és kiábrándultságról tanúskodó regényében, az Ahol a pénz nem isten című robinzonádban a hajótörött egy, a Nauticán, a fiumei Magyar Királyi Tengerészeti Akadémián végzett magyar ifjú, a sziget pedig, ahol átmenetileg új otthonra lel, egy, a világ hívságaitól elzárt, a pénzt nem ismerő és nem használó, ideális erkölcsű kis közösség hazája.

Jókai jól ismerte a magyar tengerhajózás viszonyait. Alapításától, 1881-től haláláig igazgatósági tagja volt az Adria Magyar (Királyi) Tengerhajózási Részvénytársaságnak, ${ }^{12}$ közvetlen tapasztalatokat szerezhetett tehát a tengerhajózásról csakúgy, mint azokról a pénzügyigazdasági viszonyokról, amelyek azután valamiért arra késztették, hogy egy, a kapitalizmus viszonyaitól mentes szigetet álmodjon meg utolsó regényében. A csalódott végszó ellenére elmondhatjuk, hogy Jókai Mór kiállt Fiume nagy ügye mellett, s tőle egyáltalán nem szokatlan módon, szépírói tehetségét és tekintélyét is a politikai-nemzeti cél szolgálatába állította. ${ }^{13}$ Egy képviselőházi felszólalásában amellett érvelt, hogy a tengerpart magyarrá tételének munkáját tudatosan el kell végezni, nem fog ugyanis magától megtörténni: „Amilyen nagyon csalatkoznak azok a hazafiak, akik azt hiszik, Fiume engedi magát horváttá tenni, éppen olyan nagy a tévedésük azoknak a magyar honfiaknak, akik azt képzelik, hogy Fiume magyarrá akar lenni s egyszerúen be akarja magát kebeleztetni Magyarországba, mint Miskolcz vagy Kecskemét" ${ }^{14}$

A szépirodalom Jókai mellett és után is gyakran választotta témájául vagy díszletéü a magyar tengermelléket. Herczeg Ferenctől Tormay Cécile-en át Kosztolányi Dezsőig példák sora mutatja, hogy a különös, de mégis jól ismert vidék kezdett a magyar irodalmi tradíció részévé válni.

nique Kirchner Reill: A Poet's Struggle for a Nerw Adriaticism in the Nineteenth Century. Austrian History Yearbook XLII(2011). 3-15.

10 György Sándor: A fumei cápa. Uborkaszezoni sajtókacsa, vagy vérengzó fenevad? https:// napitortenelmiforras.blog.hu/2016/09/01/a_fiumei_capa. (Utolsó megtekintés: 2018. júl. 25.)

11 Kónya Judit: Utószó = JóKaI Mór: Egy játékos, aki nyer. Három márványfej. Szépirodalmi, Bp., 1961. 596.

12 A cégnév két változatának magyarázata, hogy a „Királyi” jelzőt csak 1891-től viselte a részvénytársaság, amikor Baross Gábor kereskedelemügyi miniszter javaslatára államilag segélyezett és ellenőrzött, gyakorlatilag nemzeti szállítmányozási vállalattá vált.

13 Cieger András: Jókai Mór, a profi politikus? Aetas 32(2017). 2. sz. 9.

14 Jókai Mór felszólalása az 1881. szeptember 24-én kezdődő ülésszakban. https://library.hungaricana. hu/hu/view/OGYK_KN-1881_01/?query=SZO\%3D(Fiume\%20engedi\%20mag\%C3\% A1t)\&pg=52\&layout=s. (Utolsó megtekintés: 2018. júl. 25.) 
Rövid idő alatt a tenger gyermek- és ifjúsági irodalma is megszületett. Megteremtője, Vittorio de Gaus, magyar nevén Garády Viktor sajátos figurája volt a fiumei szellemi életnek. Olasz patrícius családból származott, később azonban - névváltoztatása és teljes életműve is erre enged következtetni - magyar öntudatúvá vált. Rendkívül gazdag életmúve szinte teljes egészében a magyar tenger szolgálatáról tanúskodik, hazafias ismeretterjesztő írásainak megjelentetése mellett 1905-tôl ő lett a fiumei Biológiai Intézet igazgatója is, amely intézmény a magyar tengerbiológiai kutatások számára állíttatott fel. Az intézet megszervezéséből arra következtethetünk, hogy a magyar állam komolyan vette a tenger birtokbavételével járó feladatokat, s erőforrásokat szánt annak tudományos megismerésére. Garády termékeny szerző volt, a $M i$ van a tengerben? című műve a tenger élővilágát mutatja be, az Adria gyöngye. Magyar fiú a magyar tengerparton a hajózás ismereteit igyekszik átadni a gyerekközönségnek, de sokat írt a magyar történelem nagy pillanatairól, és természetesen a magyar-olasz-fiumei közös múlt dicsőséges momentumairól is. ${ }^{15}$

A szép- és a tényirodalom határán elhelyezkedő utazási irodalom nyilvánvaló eszköz volt az anyaországiak irányában történő ismeretterjesztésre. 1884-ben jelent meg az első magyar útikönyv az Észak-Adriáról, Kenedi Géza A Quarnero, Fiume és Abbázia című műve, ${ }^{16}$ amelynek hamarosan számos követője akadt. Herman Ottó $A$ tenger szinén - Adriai képek címú változatát folytatásokban a Vasárnapi Újság is leközölte.

Az utazási irodalom egyik célja értelemszerűen az adriai utazások ösztönzése volt, s szintén ez irányba hatott a kialakulóban lévő turisztikai infrastruktúra is. A Magyar Turista Egyesület megalakulását követően még az első hónapokban létrejött a fiumei osztály, s ez a szervezet később a nagy hatású Kárpát-Egyesületbe tagozódott be. A turizmus terén is kiemelt figyelmet kapott az ifjúság, illetve nevelőik - 1887 nyarán például nem kevesebb, mint 150 középiskolai tanár - üdültetése Fiumében, s ha hihetünk a Fiume címú lap cikkének, az 1880as években évente 36 magyarországi iskola diákjai kirándultak a magyar tengerpartra. ${ }^{17}$ Fest Aladár, a Fiumei Magyar Királyi Állami Főgimnázium igazgatója az ellenkező irányban is szorgalmazta a nyaraltatást, meg kívánta teremteni annak a lehetőségét, hogy a felsőbb osztályok nem magyar tanulói a nyári szünidőt magyar városokban tölthessék. ${ }^{18}$ Menetjegyirodák, árkedvezmények, szervezett utazások igyekeztek megkönnyíteni az elhatározást az anyaországiak számára, s természetesen az a körülmény, hogy 1873-tól Fiume Budapestről közvetlen MÁV-vasútvonalon is megközelíthetôvé vált, ugrásszerűen megnövelte a városba látogató turisták számát. 1888-tól a zónatarifa olcsóbbá, 1896-tól a heti kétszer indított luxusvonatok kényelmesebbé tették az utazást. ${ }^{19}$

Fest Aladár fógimnáziumi tanár a város magyar kulturális életének több évtizeden át volt talán a legaktívabb szervezője - az általa alapított hetilap az első igazán fontos magyar nyelvű sajtótermék volt Fiuméban. A lap címe Magyar Tengerpart volt...

15 FRIED Ilona: Egy kulturális identitás. Vittorio de Gaus - Garády Viktor = Fiume és a magyar kultúra. 118-128.

16 Kenedi Géza: A Quarnero, Fiume és Abbázia. Légrády, Bp., 1884.

17 Idézi Misóczкi Lajos: Fiume és környékének idegenforgalma a 19-20. század fordulójáig = A tudós tanár. Tanulmányok a 60 éves Gebei Sándor professzor tiszteletére. Szerk. Besze Tibor-Miskei Antal. EKF Líceum, Eger, 2007 (Acta Academiae Pedagogicae Agriensis. Nova Series XXXIV). 229-245.

18 VARga Csilla: Magyar nyelvkönyvek a XIX. századi Fiuméban = Fiume és a magyar kultúra 63.

19 Frisnyák Zsuzsa: Megy a gözös... História XVIII(1996). 5-6. sz. 47. 
A magyar tenger megismertetése és a fogalom terjesztése a természettudományos ismeretterjesztés kereteiben is megtörtént. A már említett Biológiai Állomás mellett az 1872-ben alapított Magyar Földrajzi Társaság élen járt a területet érintő, korábban hiányzó geográfiai alapkutatások elvégzésében, és az eredmények terjesztésében is. ${ }^{20} \mathrm{~A}$ meteorológia, a geológia, az állat- és növénytan érdeklődése hasonlóképpen kiterjedt a tengerparti sávra. A (természet)tudományos tudástermelés egyszerre nemzeti és nemzetközi irányultságú gyakorlat, amely formálja a közgondolkodást és a politikai döntéshozatalt egyaránt, míg önmaga is a nemzetépítő törekvések befolyása alatt áll. Mind a nemzetközi, mind a hazai szakirodalom felfigyelt arra a jelenségre is, hogy az általában értéksemlegesebbnek tekintett természettudományok is milyen nagy mértékben álltak a nacionalista programok hatása alatt, illetve milyen nagy mértékben járultak hozzá az említett programok megvalósításához. ${ }^{21} \mathrm{~A}$ számos hazai és nemzetközi példa, valamint az ismeretterjesztő szövegek tanúsága alapján bátran állíthatjuk: a magyar-horvát tengermellék feltérképezése és megismerése sem volt politikailag semleges tevékenység.

A humán tudományok, mindenekelőtt a történelem és a néprajz, szintúgy kivették a részüket a tengerpart viszonyainak ismertté tételéből, s mindezen erófeszítések szintézise volt a Sziklay János és Borovszky Samu szerkesztésében megjelent Fiume és a magyar-horvát tengerpart címú kötet, ${ }^{22}$ a Magyarország vármegyéi és városai sorozat része, amely célul túzte ki a régió történeti, földrajzi, képzőművészeti, néprajzi, hadügyi és természeti viszonyainak, közművelődési és közgazdasági állapotának bemutatását.

A legkülönbözőbb tudományterületek eredményeinek összegyűjtésére és közlésére egy évtizeddel később már a Gonda Béla által alapított Magyar Adria Egyesület vállalkozott. Gonda, aki mai szóval műszaki értelmiségi volt, az ismeretterjesztés felé is elköteleződött, és az általa alapított $A$ Tenger című havilap programadó első számában így foglalta össze a kitüzött ambiciózus célokat: „Nagyok, és sokfélék a feladatok, melyek megoldását az Egyesület maga elé tüzte. A tengermellék sok százados magyar történelmi, néprajzi, müvészeti emlékeit felkutatni, lehetóleg összegyüjteni, a partok, a hegységek, a völgyek, patakok, források alkatát, eredetét, természetét tanulmányozni, a légköri viszonyokat és jelenségeket megfigyelni, a tenger vizének, árjainak mivoltát, változásait felderiteni, a tenger mélyének csodás állat-és növényvilágát, annak változatos életjelenségeit behatóan tanulmányozni, figyelemmel kisérni a kereskedelmi és hadi tengerészet fejlödését, a tengeri kereskedelem, a tengerparti ipar szükségleteit, életfeltételeit stb, mind oly nagyfontosságú s az ország kulturális és gazdasági fejlódésére oly kiváló jelentöségú feladatok, melyek megér-

20 A földrajztudomány és a nemzetépítés kapcsolatáról a térség kontextusában lásd Eszıк Veronika: A magyar-horvát tengermellék mint nemzetiesitett táj. Adalék az intézményesülö földrajztudomány és a nemzetépités kapcsolatáboz. Korall 16(2015). 62. sz. 75-96.

21 The Nationalization of Scientific Knowledge in the Habsburg Empire, 1848-1918. Eds. Mitchell G. Ash-Jan Surman. Palgrave Macmillan, Basingstoke, 2012; Cieger András-Varga Bálint: Tudomány és müvészet a magyar nemzetépités szolgálatában. Szöveggyüjtemény. MTA BTK, Bp., 2017 (Tanulmányok a Nacionalizmus Kultúrtörténetéből 6).

22 Fiume és a magyar-horvát tengerpart. Szerk. SzikLay János-Borovszky Samu. = Magyarország vármegyéi és városai (Magyarország monográfiája). A magyar korona országai történetének, földrajzi, képzömüvészeti, néprajzi, hadügyi és természeti viszonyainak, közmüvelödési és közgazdasági állapotának enciklopédiája. Szerk. Borovszky Samu-Sziklay János-Csánki Dezső. 6. Apolló Irodalmi és Nyomdai Részvénytársaság, Bp, 1897. 
demlik, hogy az ország tudományos és gyakorlati szakembereinek szine-java egyesüljön ezeknek a nagy feladatoknak a megralósitására". ${ }^{23}$

A szerző hangsúlyozta: a feladatot magyar tudósoknak kell elvégezniük. Nem csupán gyakorlati szempontok miatt, vagyis mert az adott területről szerzett tudás ellenőrizhetőbbé és kiaknázhatóbbá teszi azt, hanem mert a magyar nemzeti kultúrának saját eredményekkel kell hozzájárulnia az egyetemes tudományhoz, emelvén a „a nemzeti kultura prestige-ét a külföld elött" ${ }^{24}$ A cél érdekében az Egyesület összesen hét szakosztályt állított fel: történelmi, néprajzi és múvészeti, földrajzi, állattani, növénytani, tengerészeti, valamint közgazdasági részlegekre oszlott. Az Egyesület kiterjedt ismeretterjesztő tevékenységében felolvasások, könyv- és folyóirat-kiadás, egy budapesti tengerészeti múzeum terve és adriai utazások szervezése, támogatása kapott helyet. Gonda meg volt győződve ügyének kiemelkedő jelentőségéről, nagy energiákkal kezdett a szervezésbe: „Teljes tudatában vagyunk annak, hogy nagy és nehéz feladatokra egyesültünk. De erôt és kitartást ad e feladatok megvalósitásának kiváló tudományos és nemzeti jelentôsége s bizva-bizunk abban, hogy az arra bivatott tényezők s a müvelt magyar közönség teljes odaadással támogatni fognak nemes és hazafias törekvéseinkben". ${ }^{25}$

A természet- és humántudományok eredményei tehát rákerültek a térképekre és bekerültek a (tan)könyvekbe - a magyar tengerpart múltjáról és jelenéről felhalmozott tudás elérhetővé vált, és mind szélesebb körökben honosodott meg.

Tanulmányomban szövegek elemzésével foglalkozom, de természetesen a magyar tenger a képzőművészetekben is jelen volt, s a különböző hazai és nemzetközi kiállításokon az ország eredményeinek reprezentációjából sohasem maradt ki a tengeri kikötő teljesítményének ünneplése.

Noha ez a lista nem törekedhet teljességre, talán érzékelhetővé tette ennek az integrációs kísérletnek a dimenzióit, azt, hogy milyen szerteágazó területeket vont szolgálatába, milyen sokféle szellemi és anyagi erőt vett igénybe a magyar tenger elfogadtatására.

\section{A TENGER BIRTOKLÁSÁNAK LEGMODERNEBB MÓDJA}

Az említett területek szövegtermésének közös pontjait keresve feltűnő, hogy, amint arra már a Jókai-regények kapcsán utaltam, a magyar tengerpart legfőbb jellemzőjévé modernitása vált. 1905-ben Herczeg Ferenc például Trau város leírásában ütköztette a látványos progressziót és a lokális társadalmak megrekedtségét: „Íme a múmiává aszott múlt, mely máig sem tud a maga haláláról, hanem furcsa vámpíréletet él ösrégi házak és szúkmellú utcák közt, a tündöklö szépségú dóm tövében. (...) A házak homályában, fakó, csendes asszonykák motoszkálnak. És nem tudnak róla, hogy Bua szigetén túl tízezer lóerővel vágtat az óceánjáró újkor (Kiemelés tőlem - E. V.). Ha néha napján cirkáló torpedónaszád vagy fumei kiránduló gózös téved az iszapos kikötóbe, akkor a sistergö-tülkölö anakronizmus valóságos szívfájdalmat okoz az embernek...". ${ }^{26}$

\section{Gonda: i. m. 2 .}

24 Uo.

25 Uo. 3. Gonda munkája a kikötőépítésről: Gonda Béla: A magyar tengerészet és a fumei kikötő. Pátria, Bp., 1906. A Magyar Adria Egyesület jelentősége az első világháborút követően sem csökkent, sőt, részt vállalva a revizionista programban, presztízse tovább növekedett.

Herczeg Ferenc: Szelek szárnyán = Adriai képek 96-116. 
Fontos megjegyeznünk, hogy a modernitás és a tengerpart magyar jellege közötti képzettársítás részben abból a kényszerből adódott, hogy Fiume városában a magyar elit nem élhetett a szimbolikus politika hagyományos eszközeivel. A város önkormányzatát és saját hagyományait a magyar vezető rétegek mindvégig tiszteletben tartották - ez volt a záloga az olasz vezető rétegek magyarbarátságának, amely a horvát igények miatt nélkülözhetetlen támasza volt a tengermelléki kormányzásnak. Így tehát emlékmű- és szoborállítás, magyar lobogók, címerhasználat vagy megemlékezések nem képezhették részét a tengerpart integrációjának. Ennek két fontos folyománya volt: egyrészt ilyen körülmények között a magyar tenger megalkotása döntően szövegekben valósult meg, vagyis ennek a szimbolikus politizálásnak a hangsúlyai a régióval kapcsolatos diskurzusra tevődtek. Másrészt a magyar elitek azon vélekedése, hogy a modernizáció önmagában integrációhoz fog vezetni, vagyis hogy a magyar állam valóban lenyűgöző modernizációs műve egyúttal az állameszméhez való lojalitást fogja eredményezni, ${ }^{27}$ nagyobb jelentőségre tett szert, mint az országban bárhol. Ez az illúzió a nemzeti aktivisták attitűdjére a nem magyarlakta, ún. nemzetiségi területekkel kapcsolatosan általánosságban is hatott, de a tengermelléken egészen más léptékben jelent meg: a modernizáció nem egyszerúen az integráló tényezők egyike volt, hanem az egyetlen.

A tenger birtoklásának modern módja a gőzhajózás megteremtése és múködtetése volt. A gőzhajó teljesítménye, menetidejének kiszámíthatósága, biztonságosabb üzemmódja miatt egyrészt jövedelmezőbb volt elődjénél, másrészt a természet kontrollálásának, sőt leigázásának modern élményét jelentette. Az idézett szövegrészben, metaforikus megfogalmazásban ez a tétel így hangzott: „tízezer lóerövel vágtat az újkor”.

A világ hajózásában éppen ez idő tájt zajló szerkezetváltás, vagyis a vitorlás hajózás kiszorulása a gőzhajózás javára, a magyar tenger esetében együtt járt a hajóépítő, -tulajdonos és hajós elit lecserélődésével. A hihetetlenül tőkeigényes gőzhajózást csak állami segélyezésű vállalatok tudták felépíteni, majd jövedelmezően múködtetni, mind a parthajózásban, mind a távolsági kereskedelem területén. Vagyis az évszázadok óta vitorláshajó-építésből és hajózásból élő tengermelléki olasz és horvát elit helyére, amely maga képtelen lett volna a tôkeigényes szerkezetváltáshoz való alkalmazkodásra, állami tőkéből magyar, illetve osztrák-német gazdasági szereplők léptek. A gazdasági-társadalmi átalakulást környező feszültség ilyen körülmények között magától értetődően etnicizálódott, és könnyen tűnhetett rivalizáló nemzeti programok konfliktusának.

A magyar gazdasági szereplők közül az elsőség egyértelmúen a már emlegetett Adria Tengerhajózási Rt.-t illette. Az eredetileg angol és osztrák tulajdonosok által alapított társaságot 1880-ban vásárolta ki az állam, s egy év alatt teljesen magyar tulajdonú részvénytársasággá tette. A cég a tekintélyes évi állami segélyért cserébe biztosította a magyar gazdaság számára legfontosabb kereskedelmi útvonalak kiszolgálását, és lassanként tekintélyes flottát épített ki. Fénykorában több, mint harminc nagy teljesítményű, a legmodernebb technikával ellátott gőzhajó közlekedett magyar lobogó alatt a világtengereken, s természetesen a hajók a magyarság nagyságát hirdető felületként is szolgáltak elnevezésük által is. A részvénytársaság működésének első tíz évében jellemző volt, hogy valamiképpen az Adriához és a horvát-magyar együttéléshez kapcsolódó jelentôs figurák lettek a hajók névadói, illetve még konkrétab-

27 VARga Bálint: Árpád a város fölött. Nemzeti integráció és szimbolikus politika a 19. század végének Magyarországán. MTA BTK, Bp., 2017 (Tanulmányok a Nacionalizmus Kultúrtörténetéből 3). 13. 
ban az igazgatósági tagok neveit kapta egy-egy új gőzös, így lett Jókai, Szapáry, Tisza vagy Baross nevü hajó.

Utóbbi azonban korszakváltást is jelentett. Baross Gábor kereskedelemügyi miniszterré való kinevezését (1889) követően óriási energiákkal szervezte át a gőzhajózást is. A magyar tengeri kereskedelem ügyét leválasztotta a nem elég hatékonyan működő Osztrák-Magyar Lloyd-vállalatról, s komoly állami segélyezés fejében az „Adriára” bízta az ország külkereskedelmi érdekeinek képviseletét. A társaság ezután az egyetlen 1892-es üzletévben tizenegy új hajót vásárolt, amelyek elnevezése jellemzően már nem a helyi viszonyokra utalt. Árpádtól Deákig a nagypolitika, az országos történelem kiemelkedő alakjai jelentek meg a gőzösökön. ${ }^{28}$ A változás nem maradt észrevétlen. Antun Radić, a horvát agrárius gondolat kiemelkedő alakja, később a Horvát Parasztpárt társalapítója és legfőbb teoretikusa felháborítónak találta az „Adria” névadási gyakorlatát: „Dalmáciában (...) nincs igazi élet a tenger nélkül. És ki az úr a tengeren? Elég elolvasni, hogy nevezik a hajókat: itt egy "Árpád ", egy »Báthory", egy "Széchenyi«, itt egy »Zichy «, egy »Petöfi e, egy »Szent István «, és megint csak egy »Mátyás király«. (...) mindenki tudja: magyar név-magyar pénz". ${ }^{29}$

Baross minisztersége alatt a magyarság fiumei városi jelenléte is markánsabbá vált. Az állami reprezentáció a már említett okok miatt érintetlenül hagyta a város szövetét, és szinte kizárólag a tengerfeltöltés útján létrejövő, teljesen új városrészre koncentrálódott. Ide került nemcsak a modern ipar minden épülete, de a reprezentatív pályaudvar (Pfaff Ferenc), a Petz Samu-féle Tengerészeti Hatóság és a Freund Vilmos tervezte Adria-palota is. Utóbbinak a tenger felőli homlokzatát Ligeti Miklós négy szobra díszíti, négy férfialak: egy matróz, egy hajógépész, egy kapitány s végül egy kormányos. A művész saját szavai szerint négyük közül a hajógépész a legerőteljesebb figura, hiszen a megújult, immár gőzüzemű hajózásnak ő a kulcsfigurája. ${ }^{30}$

Az Adria levéltári anyagából kiolvasható az építkezés pénzügyi háttere. Az igazgatóság 1894-es üzleti jelentése ${ }^{31}$ beszámol arról, hogy a palota céljaira sikerült egy 600 négyszögöles telket vásárolni, mely a tengerparton, a főút mentén áll, s mind a négy oldalán utcák határolják - vagyis különálló palota építhető rá. Az Adria a telket 180000 forintért vásárolta a magyar államkincstártól, de azt csak 18 év alatt, évi 10000 forintos, kamatmentes(!) részletekben kellett kifizetnie. (Valójában levonták az ekkor már sok százezres évi állami támogatásból.) A telek tehermentes tulajdonjogát viszont azonnali hatállyal bejegyezték, így a cég kedvező jelzáloghitelhez juthatott az építkezés fedezésére, 300000 Ft. értékben. A törvényhozás további húszévnyi adókedvezményt szavazott meg a bérpalota múködésének azzal a feltétellel, hogy az 1896. év végéig felépül. Az Adria lényegében alig fordított saját pénztartalékot az építkezésre. A magánvállalat palotája egyértelmúen az állami reprezentáció részét képezte az egyet-

28 Budapest Fóváros Levéltára (a továbbiakban BFL), Cégbírósági iratok 1876-1949, VII. 2. e. - Az „Adria” Magyar Királyi Tengerhajózási Részvénytársaság iratai (a továbbiakban VII. 2. e.), Üzleti jelentés az 1892-es évről.

29 Antun Radić: Dalmacija. Dom II(1901). 7. sz. 114. A nevek a forrásban fonetikus átírásban szerepelnek, fordításkor a bevett magyar helyesírás szerint javítottam őket.

30 https://www.kozterkep.hu/ /18447/adria_palota_diszitoszobrai_fiume_rijeka_ligeti_ miklos_1897.html. (Utolsó megtekintés: 2018. júl. 25.); Ligeti T. Miklós-Ligeti Gábor: Töredékek Ligeti Miklós befejezetlen memoárjából. Ars Hungarica 33(2005). 2. sz. 473-502.

31 BFL, VII. 2. e., Üzleti jelentés az 1894-es évrő1. 
len magyar tengeri kikötóben, s nem sokkal később budapesti párja is megépült az országház szomszédságában.

\section{ÖSSZEGZÉS}

Végül fel kell tennünk azt a kérdést, hogy sikerrel járt-e ez a grandiózus szimbólumteremtési kísérlet. 1883-ban magyarellenes megmozdulások törtek ki Zágrábban, mivel a Pénzügyi Igazgatóság falára kitett kétnyelvű feliratokat a város lakossága joggal a kiegyezés megsértéseként értelmezte. A tüntető tömeg leszedte a táblákat, és azokat a „Magyar tenger” gúnynevet viselő Medveščak-patakba dobta. A patak annak köszönhette csúfnevét, hogy a partja mentén álló bordélyházakban számos magyar prostituált dolgozott, ${ }^{32}$ a gesztus tágabb értelemben nyilvánvalóan arra utalt, hogy Magyarország fiumei politikája ellenére a közvélemény egyértelmúen horvátnak tartotta a tengerpartot, és annak magyar kisajátítása ellen hevesen tiltakozott. Utal azonban arra is, hogy a horvát kortársak számára a magyar tenger fogalmának meghonosítása érzékelhető volt, sőt olyan egyértelmű gesztus, amelyet könnyedén ki is lehetett figurázni.

A fiumei olasz sajtó a Magyar Tengerpart címú lap alapításakor fogalmazott úgy, hogy "programadó címadás" történt, ${ }^{33}$ vagyis a szándék ugyan megvan, de az a tengerpart bizony nem magyar még. S maga a magyar közvélemény is teremtett egy konkurenst a fogalomnak, amikor mind gyakrabban a Balatont nevezte magyar tengernek. Szinnyei Ottmár Magyar lobogó alatt az Ádrián című útleírásában beszámol egy csalódást keltő esetről. Zárában a helyiek hosszan találgatták, honnan jöhetett, de sem a magyar szót, sem a hajón lobogó zászlót nem ismerték fel. ${ }^{34} 1892-t$ írtak ekkor, már húsz éve létezett a magyar tengerhajózás, s ebben a formájában már alig több, mint húsz éve volt hátra.

Tanulmányomban egy sajátos nemzeti integrációs kísérlet politikai, gazdasági, tudományos, történeti és kulturális aspektusait igyekeztem felvázolni annak érdekében, hogy további adalékokkal szolgáljak egy rendkívül sokszínú, így nagyon különböző olvasatokkal rendelkező területről. Az adriai térségre nézve egy sor, egymással versengő nemzeti narratíva jött létre, amelyek mindegyike igyekezett a maga számára kisajátítani a tengert és a tengerparti sávot. Ezek közül a magyar nacionalizmus programjának sajátossága volt, hogy a nemzeti karaktert az állami irányítású modernizáció vívmányai határozták meg és reprezentálták.

A haladás úttörőjének, a fejlődés előmozdítójának figurája nem volt szokatlan a 19. század nyugat-európai népeinek önreprezentációjában, de viszonylag ritkán jelent meg magyar kontextusban, ahol az önképet elsősorban „az intenzíven basznált autentikus paraszti múlt” ${ }^{35}$ határozta meg. ${ }^{36}$ Azáltal, hogy ebben az integrációs narratívában a pásztorokat és a csikósokat

32 Sokcsevits: i. m. 395.

33 Fried Ilona: Emlékek városa Fiume. Ponte Alapítvány, Bp., 2001. 146.

34 Szinnyei Ottmár: Magyar lobogó alatt az Adrián = Adriai képek 202-229.

35 ILYÉs Zoltán: Etnicitás és szimbolikus geográfia. A táj kisajátitása, különösen határvidékek, kontaktzónák esetén = Etnicitás. Különbségteremtó társadalom. Szerk. Feischмidт Margit. Gondolat-MTA Kisebbségkutató Intézet, Bp., 2010. 115. (https://kisebbsegkutato.tk.mta.hu/uploads/files/ olvasoszoba/intezetikiadvanyok/Etnicitas.pdf - Utolsó megtekintés: 2018. júl. 25.)

Nyilvánvaló kivétel továbbá a boszniai kontextus. 
hajóskapitányokra és hajógépészekre cserélték, egyértelmű legitimációt teremtettek a térségben gyakorolt magyar uralomnak. Magától értetődő volna ezt a jelenséget a (poszt)kolonializmus fogalmi keretei között civilizációs küldetéstudatként azonosítani, és további expanziós törekvések kiindulópontjaként láttatni. ${ }^{37}$ De nem feltétlenül erről volt szó. A fiumei olasz kultúra egyenesen olyan színvonalat képviselt, amelyhez a városban megtelepedő magyarság felzárkózni kívánkozott. A világtengereken való megjelenés magának az anyaországnak is civilizációs ugrást jelentett, ahogyan Fest Aladár lelkesülten megfogalmazta: a magyarság végre eljutott „az oceanikus müveltség fokára” (ti. a folyó menti és a középtengeri szinteket követően). ${ }^{38} \mathrm{~A}$ vázolt integrációs projekt tehát nem valamiféle civilizációs küldetéstudatból táplálkozott, hanem beszorulva a tengermellék vitatott hovatartozása miatt kialakult bonyolult jogi és geopolitikai helyzetbe, egyetlen tényezőt vélt minden konfliktust felülíró integráló erőnek, s ez a korszak varázsigéje, a haladás volt.

\section{"TO BRING THE SEA CLOSER TO THE HEART OF THE COUNTRY". THE MAKING OF THE HUNGARIAN ADRIATIC 1868-1918}

\section{Keywords: Adriatic, nationalized space, symbolic politics, modernization, steamboating}

Following the Austro-Hungarian Settlement, the Hungarian-Croatian Compromise (1868) (re)defined the relation of landlocked Hungary and maritime Croatia, granting the latter limited homerule within the framework of the Kingdom of Hungary. During the negotiations, the parties could not agree on the question regarding the possession of the port city Fiume (today Rijeka, Croatia), which lay on Croatian soil but was administered directly from Hungary. The legal status of the only maritime port of Hungary, extremely important for Hungarian economic and national ambitions, remained contested until the end of the era. In these circumstances, the stakes of symbolic politics grew enormously, as the Hungarian political elite tried to make the concept of the Hungarian littoral accepted and familiar to every citizen of the Austro-Hungarian Monarchy.

In the first part of my paper, I investigate different areas of symbolic politics and nationalist representation (belles-lettres, travel, scientific, popularising and juvenile literature, press, political discourse etc.). With the help of this enumeration, I aim to show the dimensions and variety of this effort to construct a new nationalized space, the so-called Hungarian littoral.

The second part of the paper will detail a specific way of making the Hungarian littoral: the establishment of the Hungarian steam boating. Steam boating, on contrary to traditional sailing, represented a modern way of possessing the seaside and controlling the sea. As a result, modernity and the Hungarian character were inherently linked in the Hungarian national discourse on the littoral. This

37 S természetesen imperialista látásmódra van is kortárs példa. Havass Rezső, előbb a Magyar Földrajzi Társaság alelnöke, majd tiszteletbeli elnöke például egyértelműen úgy gondolt Fiumére, mint a Balkán felé irányuló további területszerző és civilizáló akciók kiinduló bázisára, ilyen értelemben ő a Balkán-orientációjú magyar imperializmus képviselője. Álláspontja azonban semmiképpen sem tekinthető sem általánosnak, sem hivatalosnak. Havass Rezső: Dalmáczia Magyarországhoz való vonatkozásaiban különös tekintettel Fiumére. Fritz Ármin Könyvnyomdája, Bp., 1898. Összefoglalóan Demeter Gábor: A modernizációtól a kolonizációs törekvésekig. Magyar utazók, politikusok és gazdasági szakirók a balkáni feladatokról (a 19. századtól az annexiós krizisig). Századok 152(2018). 2. sz. 284-316.

38 Fest Aladár: Fiume és a millenium. Magyar Tengerpart 1893. február 12.2. 
interconnection was the differentia specifica of the Hungarian variant among many rival national attempts to appropriate the sea, and was a rather rarely used trope in the Hungarian self-representations. In my paper, I investigate the roots of this phenomenon.

\author{
„A ADUCE MAREA MAI APROAPE DE INIMA ŢÄRII”. \\ CREAREA ADRIATICII MAGHIARE 1868-1914
}

\title{
Cuvinte-cheie: Marea Adriatică, spațiu naționalizat, politică simbolică, modernizație, navigație cu vapori de abur
}

După compromisul austro-ungar, compromisul ungaro-croat din 1868 a (re)definit relația dintre Ungaria terestră și Croația maritimă, garantând celor din urmă doar autoguvernare limitată în cadrul Regatului Maghiar. În timpul negocierilor părțile nu au ajuns la acord comun privind apartenența portului Fiume (azi Rijeka, Croația) și a împrejurimilor acestuia, care s-a întins pe pământ croat, dar a fost administrat direct din Ungaria. Ástfel statutul legal al singurului port maritim al Ungariei, dar unul extrem de important pentru ambițiile economice și naționale maghiare, a rămas contestat până la sfârșitul perioadei. În aceste circumstanțe miza politicii simbolice a crescut enorm, deoarece elita politică a încercat să facă din conceptul de Litoral Maghiar un concept acceptat și familiar fiecărui cetățean al Monarhiei Austro-Ungare.

Prima parte a lucrării investighează diferitele arii ale politicii simbolice și ale reprezentării naționaliste (beletristica, literatura de călătorie, cea științifică, de popularizare și pentru copii, presa, discursul politic etc.). Prin această prezentare autoarea subliniază dimensiunea și varietatea eforturilor de a construi un spațiu naționalizat nou, așa-numitul Litoral Maghiar.

Partea a doua a lucrării detaliază un exemplu specific al acestei încercări de a construi litoralul maghiar: întemeierea industriei maghiare de navigație cu vapori cu abur. În contrast cu navigația tradițională, cea bazată pe puterea aburului a reprezentat o modalitate modernă de a controla marea, respectiv litoralul acesteia. Ca rezultat, în discursul național maghiar privind litoralul modernitatea și caracterul maghiar au fost strâns legate între ele. Această interconexiune a dat differentia specifica variantei maghiare dintre multele încercări ale națiunilor rivale de a-și însuși marea, fiind însă un trop destul de rar folosit în reprezentația de sine maghiară. Studiul investighează de asemenea și rădăcinile acestui fenomen. 